Elsevier/North-Holland Biomedical Press

\title{
Review
}

\section{IS HAPLOID GENE EXPRESSION POSSIBLE FOR SPERM ANTIGENS?}

\author{
ROBERT P. ERICKSON, SUSAN E. LEWIS * and MARTIN BUTLEY ** \\ Department of Human Genetics, University of Michigan School of Medicine, Ann Arbor, MI 48109, \\ U.S.A.
}

(Received 28 January 1981; accepted 30 March 1981)

The development of a spermatozoon (sperm) from a spermatid involves a complex process of differentiation during which a variety of new gene products appear. It has been generally assumed that no genetic transcription occurs after meiosis and, if this were so, that all the new sperm proteins would have to be transcribed from stored messenger RNA. However, the biochemical evidence suggests that there is no abrupt change in the rate of RNA synthesis during meiosis and that qualitative changes in RNA synthesis, to the extent that they are known, favor the likelihood of continuing messenger RNA synthesis. Experimental analyses of distorted transmission ratios of $t$-alleles and unbalanced chromosomal states in males also suggest that genes are expressed in haploid nuclei after meiosis. It is probable that spermatozoa are functionally equivalent in most respects because of intercellular bridges that create a continuous cytoplasm between developing spermatozoa, facilitating an exchange of most postmeiotic gene products. Plasma membrane proteins which are potential antigens might not be shared across the intercellular bridges but the evidence to date for haploid expression of sperm antigens is poor.

\section{INTRODUCTION}

Over the last several decades a number of papers have purported to show haploid expression of sperm antigens. If the phenomenon were true, it might provide a way for selecting spermatozoa of particular genotypes for breeding purposes, e.g. if H-Y antigen was expressed only on Y-bearing sperm, it should be possible to separate $\mathrm{X}$ - and $\mathrm{Y}$-bearing sperm on this basis. However, these reports have met many objections. In what follows we will try to provide a perspective on these objections. By way of introduction, we describe the relevant genetic mechanisms. The two chief causes of departures from Mendelian genotypic ratios at the time of fertilization are meiotic segregation distortion, i.e. the lack of random chromosomal segregation, and gametic selection, i.e. an unequal competition between gametes which differ in their haploid genome. Gametic selection is most simply explained by invoking gene expression after meiosis since this can result in phenotypic differences which could influence gamete function. Non-Mendelian ratios occasionally occur in a variety of organisms. In plants, where one male pronucleus is activated during pollen formation, the occurrence of distorted transmission ratios is common, e.g. the sugary locus in maize (Brink and Burnham, 1927). As would be expected, the haploid

\footnotetext{
* Present address: Research Triangle Park Institute, Research Triangle Park, N.C., U.S.A.

** Pressent address: School of Pharmacy, University of Colorado, Boulder, Colo., U.S.A.
} 
pollen tube nucleus is involved in RNA synthesis (Stanley and Linskins, 1974). A wellstudied example of non-Mendelian segregation is segregation distortion in Drosophila (reviewed in Zimmering et al., 1970) but there is no definitive evidence for post-meiotic RNA transcription (Kettaneh and Hartl, 1976). There is also one very clear example ( $t$-alleles; Gluecksohn-Waelsch and Erickson, 1970; Bennett, 1975), and several suggestive examples, of non-Mendelian ratios in mammals.

Gametic neutrality, which is almost universally observed, could be maintained in spite of post-meiotic gene expression by the sharing of post-meiotically expressed gene products among gametes. The fact that spermatozoal differentiation occurs in cells which partially share their cytoplasm (a quasi-syncytium) in mammals may provide an explanation for gametic equality as well as for successful fertilization by gametes which do not contain genes thought to be expressed post-meiotically (Erickson, 1973). As spermatozoa are highly differentiated cells, with many distinctive organelles and isoenzymes, it is obvious that a large number of genes must be involved in their development. The high frequency of intercellular cytoplasmic bridges between spermatocytes and between spermatids would facilitate equal sharing of messenger RNAs and proteins, while allowing exceptional spermatozoa with unbalanced chromosomal complements to receive gene products necessary for their development.

We hypothesize (1) that some genes are transcribed after meiosis in haploid, i.e. in genetically different, cells and (2) that the intercellular bridges do not always result in functionally equivalent sperm such that haploid expression of antigens would be possible. Recent advances in the biochemistry, immunology and genetics of spermatogenesis which illuminate these hypotheses will be discussed. We will review the evidence that RNA is transcribed after meiosis and that this RNA may include messenger RNA. We will discuss details of $t$-allele segregation distortion which argue strongly that the genotype of spermatozoa alters their function. We shall review the data on haploid expression of sperm antigens and information from other mammalian systems which suggests that haploid expression may be an occasional occurrence. Other aspects of spermatogenesis have been reviewed (Bishop, 1968; Fechheimer, 1970; Fritz, 1973; Turkington and Majumder, 1974; Bellve, 1979; Fawcett, 1979); Beatty's (1970) review on the genetics of spermatozoa has not been surpassed.

\section{MORPHOLOGY OF MAMMALIAN SPERMATOGENESIS}

Spermatogenesis is defined as the series of cellular events which result in the production of spermatozoa. Male germ cells (gonocytes) increase in number by mitosis during early male development. At puberty they assume a position along the basement membrane of the seminiferous tubule. Their histological appearance is modified when in this new position and, in this new guise, they are termed spermatogonia. Spermatogonial mitoses increase in number with an increase in luteinizing hormone and follicle stimulating hormones at puberty (reviewed in Midgely et al., 1978). The committed spermatogonium then undergoes a clonal expansion, marked by a series of mitoses with incomplete cytokinesis, resulting in cytoplasmic bridges, approximately $1 \mu \mathrm{m}$ in diameter (Fawcett, 1972; Fig. 1). This clonal expansion typically results in 32 spermatocytes and four times as many spermatids but deviations from these numbers have been reported. 


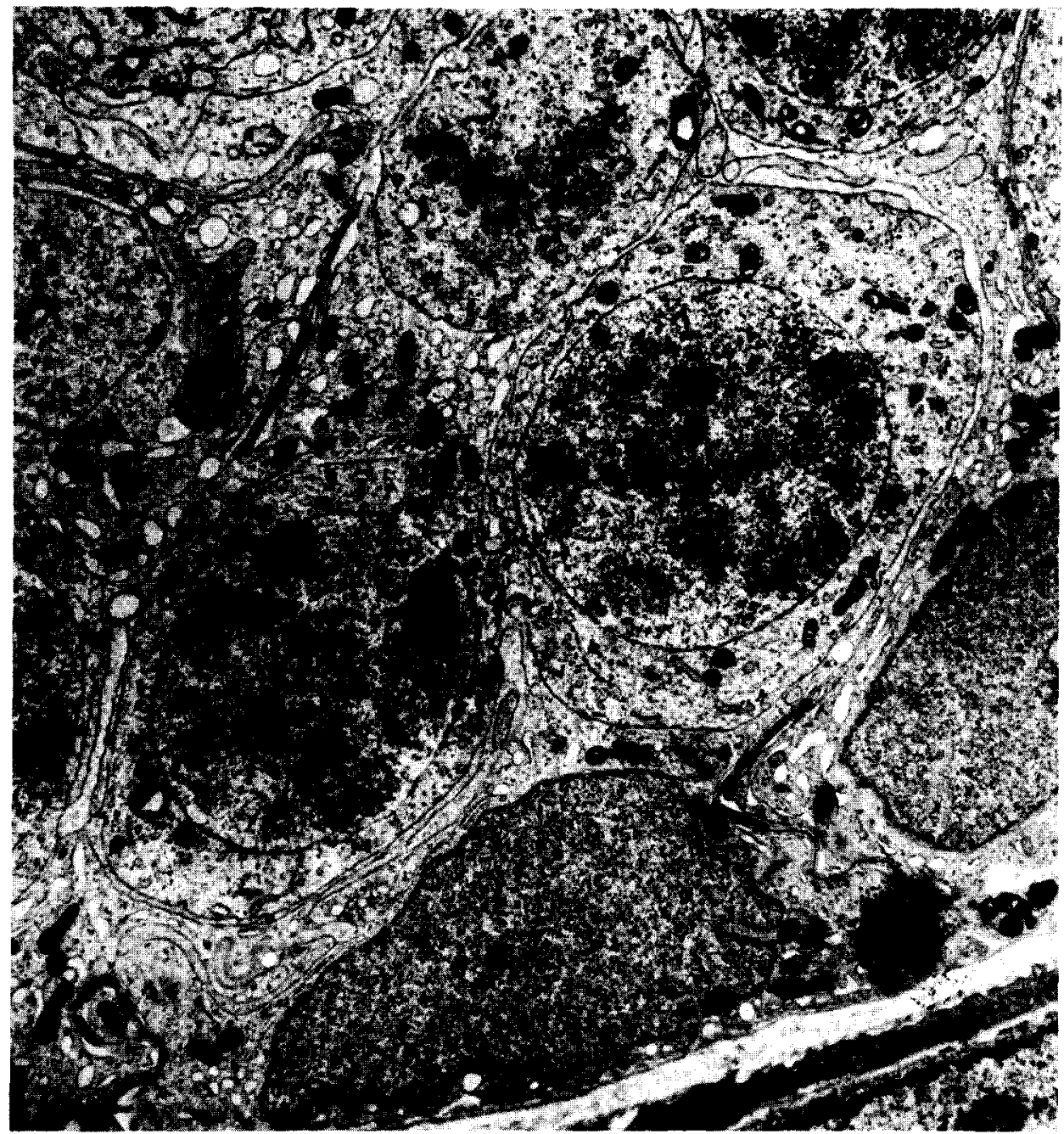

Fig. 1. Electron micrograph of an intercellular bridge between two spermatids from a rat testis. Boundaries of the bridge are continuous with the plasma membranes of the connected cells and are associated with electron-dense substance. (X 35,000). Courtesy of Dr. B. Gondos.

The number of mitoses involved in the clonal expansion and the percentage of spontaneously degenerating cells is not precisely known in any one mammalian species and varies between species. As many as 22 interconnected spermatocytes and as many as 74 interconnected spermatids have been counted in serial sections in rats (Moens and Go, 1972). Only linear, branching arrays of interconnected cells have been found in these studies; rings of cells, which would require fusion as their explanation, have not been detected (Moens and Go, 1972). These intercellular bridges seem to be maintained by specialized plasma membrane or submembrane structures (Dym and Fawcett, 1971; Beams and Kessel, 1976). The fate of these bridges during spermiogenesis (the differentiation of a 


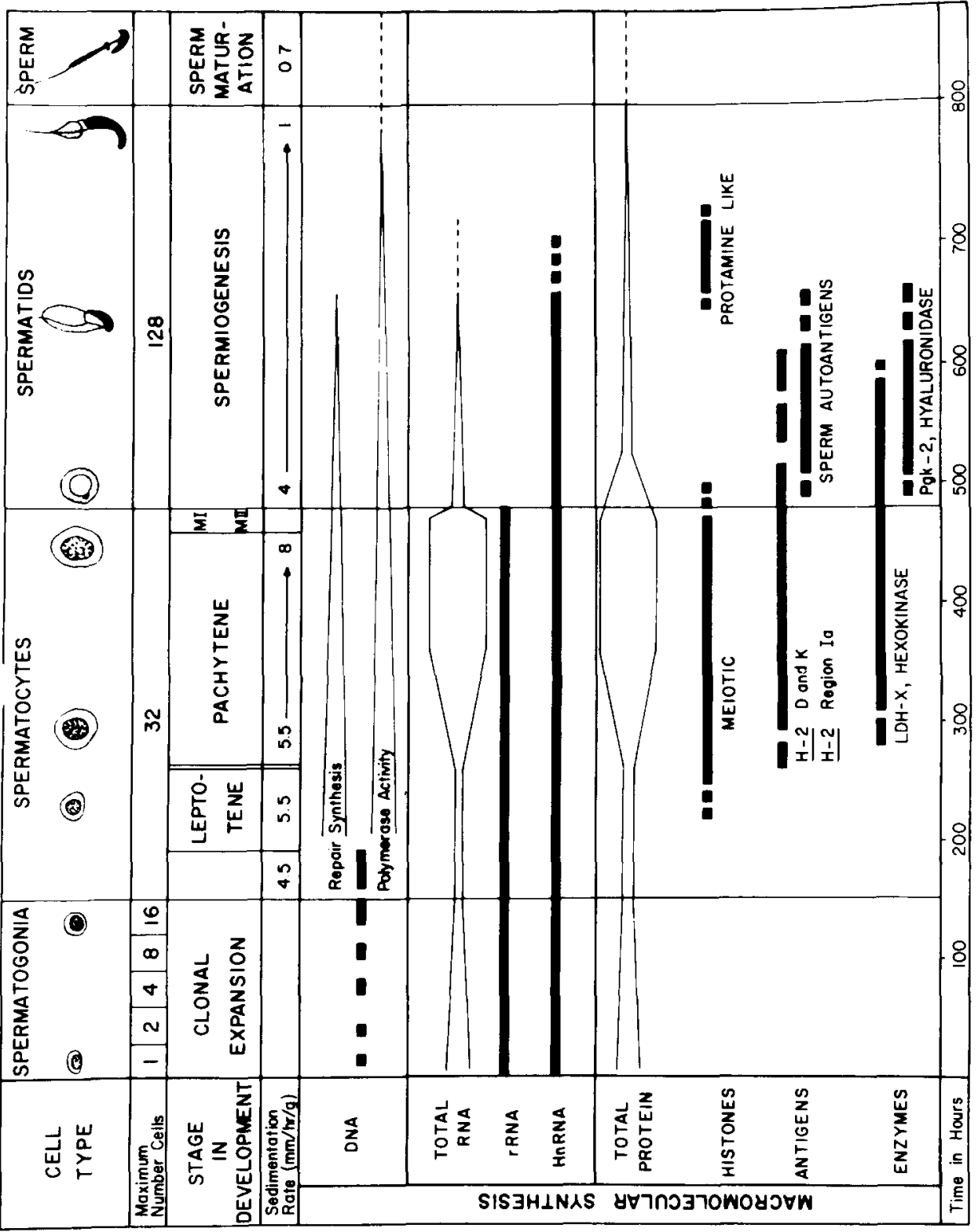

3

䒺

긍

공몬

马

总

当

娄.

인

究

ते

可

을

론

兽

동

焉

त्

음

홍

丞胥

.

.

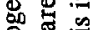

욜 若总

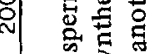

ธक

옹 专

의

焉

产

.

茟

웅

尊宁

$\varangle$ 응

实

些至送 
spermatozoon from a spermatid) is less well known, but the spermatozoa are not interconnected after their release into the seminiferous tubule. The intercellular bridges have been postulated to synchronize spermatogenic development (Schleiermacher and Schmidt, 1973). We believe that the cytoplasmic syncytia created by the intercellular bridges can provide for gametic neutrality despite post-meiotic gene expression.

The initial cellular product of the spermatogonial mitotic expansion, the spermatocyte, initially resembles a spermatogonium, but it slowly increases in size as it undergoes DNA replication and extensive RNA and protein synthesis (Monesi, 1962). The configuration of the chromosomes provides the criteria for identifying the various stages of meiotic prophase (leptotene, zygotene, pachytene, diplotene, and diakinesis). It is important to note that the spermatocyte seems to undergo its maximal synthetic activity at the pachytene stage when loops similar to those in oocyte lampbrush chromosomes have been noted (Monesi, 1965). The reductional meiotic division is rapidly followed by the second, equational, division resulting in a round cell, the spermatid, which then slowly undergoes differentiation to form a spermatozoon. The sequence of cellular stages and the accompanying macromolecular syntheses are summarized in Fig. 2.

\section{DNA SYNTHESIS DURING SPERMATOGENESIS}

Although the last major DNA synthesis occurs in pre-leptotene spermatocytes (Monesi, 1965; Kofman-Alfaro and Chandley, 1970), a low level of DNA synthesis occurs during meiotic prophase (Meistrich et al., 1975) which may be related to alterations in gene expression. Alternatively, this DNA synthesis might be involved in repair and/or meiotic pairing (Smyth and Stern, 1973). DNA polymerase activity declines to low levels during spermiogenesis, but does not decline further during sperm maturation (Daentl et al., 1977; Hecht et al., 1979). Thymidine and thymidilate kinase activities are also present in sperm (Daentl et al., 1977). The DNA polymerase activity present in spermatozoa has been thought to be mitochondrial in origin (Hecht, 1974) although histochemical and other techniques demonstrate a nuclear location (Chevaillier and Phillipe, 1976) with a ribonuclease sensitivity (Witkin and Bendich, 1977). Thus, the enzymes necessary for gene amplification, an important mechanism of gene expression in oogenesis, are present. The time of the increased DNA methylation, noted for many specific nucleotide sequences in sperm DNA (Kaputa and Sneider, 1979), is not known.

\section{RNA SYNTHESIS DURING SPERMATOGENESIS}

A large number of studies on the rates and kinds of RNA synthesis during spermatogenesis are relevant to the possibility of post-meiotic transcription. Histological studies using pyronin as the stain show little change in the amount of cytoplasmic RNA during the clonal expansion of spermatogonia (Daled, 1951). It was originally believed that little RNA was transcribed after meiosis since early mouse spermatids exposed to short pulses of $\left[{ }^{3} \mathrm{H}\right]$ uridine showed only a very small peak of uridine incorporation when examined by autoradiography (Monesi, 1967). More recent quantitative autoradiographic studies showed, however, that the rate of RNA synthesis per cell decreased only 4-fold during meiosis in ram testis, i.e. the RNA synthesis/DNA ratio was essentially unchanged 
(Loir, 1972). Furthermore, studies on mouse testicular cells separated by the Staput technique (a unit gravity sedimentation method capable of separating the cells of the various spermatogenic stages into populations that are roughly $70 \%$ pure populations - Lam et al., 1970; Meistrich et al., 1973) show that there are high rates of RNA synthesis in post-meiotic cell stages (Meistrich, 1972). In fact, in one study the highest level of $\left[{ }^{3} \mathrm{H}\right]$ uridine incorporation per cell was in early spermatids (Lee and Dixon, 1972). DNA-dependent, RNA polymerase has been shown to be active in early spermatids (Moore, 1971). These studies all depend on the incorporation of exogenous $\left[{ }^{3} \mathrm{H}\right]$ uridine into RNA. If the intracellular uridine pool size was greatly decreased in post-meiotic cells, added $\left[{ }^{3} \mathrm{H}\right]$ uridine would more quickly radiolabel the pool and label would be incorporated into RNA more rapidly, inflating the apparent rate of RNA synthesis during short pulses. However, pool size estimates indicate that the intracellular uridine pool is increasing, rather than decreasing, after meiosis (Geremia et al., 1977). Thus, although there appears to be significant RNA transcription after meiosis, the question is whether or not this includes messenger RNA (mRNA) synthesis.

In most cells about half of the newly synthesized RNA is ribosomal RNA (Harpold et al., 1979). Thus, a preliminary question focuses on whether or not ribosomal RNA synthesis is altered in post-meiotic cells. Three methods have been used to explore this question: (1) visualization of transcription units in identifiable cells, (2) characterization of newly synthesized (pulse-labelled) RNA from cells at different stages separated by differences in sedimentation velocity, and (3) studies on the time of synthesis of the ribosomal RNA which is found in spermatozoa. Kierszenbaum and Tres (1974a, b, 1975) have used whole-mount electron microscopic techniques, which allow direct visualization of the transcription process, on the spread chromosomes in combination with light and electron microscopic autoradiographic techniques, to compare RNA transcription in premeiotic and post-meiotic cells. RNA transcription in spermatocytes appears by these techniques to include both ribosomal precursor and heterogeneous nuclear RNA, but nucleolus-like, ribosomal RNA transcription patterns were not found after meiosis. Newly synthesized RNA from separated spermatogenic cells was thought to include ribosomal RNA when characterized by sucrose gradient centrifugation (Geremia et al., 1978), while electrophoresis of newly synthesized RNA suggested that ribosomal RNA synthesis decreased markedly in post-meiotic cells (Erickson et al., 1980a). Another group has found post-meiotic expression of ribosomal RNA cistrons using staining techniques (Schmid et al., 1977). However, this technique depends on the binding of silver by chromatin proteins (Bloom and Goodpasture, 1976) which are, of course, greatly altered during this stage of spermatogenesis. Studies on the time of synthesis of ribosomal RNA found in maturing mouse spermatozoa suggest that its synthesis is pre-meiotic (Betlach and Erickson, 1976).

Whether or not ribosomal RNA synthesis decreases significantly after meiosis, there is abundant evidence that heterogeneous nuclear RNA, considered to be the precursor of mRNA, is synthesized after meiosis. Early studies considered all the rapidly-labelled nuclear RNA of Chinese hamster testis to be the product of late pachytene RNA synthesis (Muramatsu et al., 1968) - heterogeneous short-lived RNA of 45-80 S with a high $\mathrm{AU} / \mathrm{GC}$ ratio similar to that of liver extranucleolar nuclear RNA was found. It is true that isolated rat primary spermatocytes largely synthesize heterogeneous RNA which is 
rapidly turned over (Grootegoed et al., 1977) but a variety of studies show that synthesis of heterogeneous RNA and RNA containing poly(A) tracts clearly continues in spermatids. Transcriptional patterns characteristic of heterogeneous nuclear RNA synthesis are found in spermatids (Kierszenbaum and Tres, 1974a, b, 1975). Sucrose gradient and electrophoretic characterization of newly synthesized RNA from spermatids demonstrate heterogeneous presumptive mRNA (Geremia et al., 1978; Erickson et al., 1980a). Some of this new RNA from spermatids is poly(A)-containing, whether determined with poly(U)-Sepharose (Geremia et al., 1978) or oligo(dT) cellulose (Erickson et al., 1980a). Similar results have been found for amphibian spermatogenesis (Kalt, 1979). Recent experiments using functional assays for mRNA (in vitro translation of specific proteins) have shown that mRNA for protamine-like histone and phosphoglycerate kinase-2 (see below) increase after meiosis (Erickson et al., 1980c). This result is most easily explained by postulating post-meiotic transcription of these messages.

A specific intracellular organelle, the chromatoid body, may be involved in the utilization of post-meiotic mRNA. This body appears during pachytene (Fawcett et al., 1970) but becomes prominent cytologically in early spermatids where it shows rapid movements between the nucleus and Golgi apparatus (Parvinen and Jokelainen, 1974). It incorporates $\left[{ }^{3} \mathrm{H}\right]$ uridine, but only after a 14 -h delay, which suggests that the RNA has to be transported from the nucleus (Soderstrom and Parvinen, 1976). Actinomycin D treatment results in depletion of putative RNA in the chromatoid body of spermatids after a 12-h interval, further suggesting that the chromatoid body contains post-meiotically synthesized RNA (Parvinen et al., 1978). Alternatively, the chromatoid body may be formed by the extrusion of nucleolar components (Comings and Okada, 1972).

The questions these data raise are relevant to early mammalian development, not just spermatogenesis. If all the mRNA synthesis during spermatogenesis is pre-meiotic, then spermatogenic post-meiotic protein synthesis must occur through 'stored' mRNA. However, stored mRNA has not yet been generally found in mammals at any stage. Unlike the situation in sea urchin and amphibian embryos, the mammalian embryo does not seem to use many mRNAs synthesized during oogenesis. RNA synthesis commences almost with fertilization and expression of the paternal genome can be detected very early, at the 8-cell stage (Wudl and Chapman, 1976; Epstein, 1975). In later mammalian embryogenesis, messages for proteins characteristic of differentiated states have been found to be accumulated briefly prior to translation. For instance, the mRNA for myosin appears in cytoplasm some hours before its translation (Buckingham et al., 1974). The synthesis of some sperm specific proteins, such as the protamine-like histone, does not begin until more than a hundred hours after meiosis. Thus, the question as to whether 'stored' mRNA is used for spermatogenic post-meiotic protein synthesis and differentiation is important.

\section{SPERMATOGENIC PROTEIN SYNTHESIS}

It is widely accepted that there is active post-meiotic translation during spermatogenesis. A moderate level of pre-meiotic protein synthesis has been demonstrated autoradiographically in early spermatocytes; this synthesis increases further and then decreases prior to the meiotic divisions, in parallel with new RNA synthesis (Monesi, 1967; see 
Fig. 2). After meiosis, autoradiography shows a peak of arginine incorporation late in spermiogenesis which most likely represents incorporation into protamine-like histone (Monesi, 1967).

Post-meiotic changes in protein composition of spermatozoa have been followed in many ways. For example, there is indirect evidence for changes in nuclear proteins as spermatogenesis proceeds. In the Bovidae, Fuelgen staining of nuclei decreases until the late spermatid stage, indicative of decreased accessibility of DNA to the stain (absorption at $265 \mathrm{~nm}$ remains constant, implying no change in the actual nucleic acid content of the nuclei). The Sakaguchi methyl green histochemical reaction, which is specific for protein-bound arginine, also increases until the late spermatid stage. There is some continuation of both these changes as the sperm progresses through the male reproductive tract, as has been found in rabbits, and with in vitro aging of bovine spermatozoa (Gledhill et al., 1966; Bouters et al., 1967; Salisbury et al., 1961). Amino acid analyses of protein hydrolysates have shown that the amino acid composition of bovine spermatozoa changes with passage through the epididymides so that some protein synthesis may continue in vivo in maturing spermatozoa (Lavon et al., 1971), although selective degradation of proteins could also explain some of these changes.

There is evidence for the post-meiotic synthesis of several sperm-specific enzymes and antigens. Among the sperm-specific enzyme with this potential are lactate dehydrogenaseX (LDH-X) (Blanco and Zinkham, 1963), hexokinase (Katzen, 1967; Sosa et al., 1972), a cyclic nucleotide phosphodiesterase (Christiansen et al., 1972), non-specific esterase (Meizel et al., 1971), an autosomally-coded phosphoglycerate kinase (Cooper et al., 1971; VandeBerg and Blohm, 1977), sperm hyaluronidase (Mancini et al., 1964; Borders and Rafferty, 1968), the acrosomal proteinase, acrosin (Stambaugh and Buckley, 1969), and testicular cytochrome $c$ (Hennig, 1975; Kim, 1980). A number of other enzymes have not yet been shown to have spermatogenic-specific isoenzymes but major changes in their activities serve as markers for various stages of spermatogenesis: sorbitol dehydrogenase (Bishop, 1967), carnitine acetyltransferase (Vernon et al., 1971), $\alpha$-glycerophosphate dehydrogenase (Posalaky, 1965), and succinic dehydrogenase (Ito, 1966). These changes in synthesis may require post-meiotic expression of regulatory proteins.

The developmental onset of enzyme activity during spermatogenesis is often instructive. For example, LDH-X activity is first found in 19-day-old male mice, which is when late pachytene spermatocytes are first observed (Goldberg and Hawtrey, 1968). Radiopulse immunoprecipitation experiments performed on fractionated cells show that synthesis continues post-meiotically, with about half of the total synthesized in spermatids (Meistrich et al., 1977). Recent data suggests that the sperm-specific hexokinase also first appears during pachytene (Brock, 1975) while spermatozoal phosphoglycerate kinase does not appear until after meiosis (VandeBerg et al., 1976; Erickson et al., 1979b; Kramer and Erickson, 1981a). Studies on testicular hyaluronidase and immunohistological localization of 3 guinea pig spermatozoal autoantigens demonstrated that these proteins first appear in spermatids or, possibly, secondary spermatocytes (Males and Turkington, 1970; Radu and Voisin, 1975). In mice, the Ia antigen of spermatozoa makes its appearance at pachytene, as may also the $\mathrm{H}-2 \mathrm{D}$ and $\mathrm{K}$ antigens (Fellous et al., 1976; Erickson, 1977a, b).

Protamine-like histones have been documented in a variety of mammals (Bloch, 1969; 
Calvin, 1976). Evidence for synthesis in late spermatids also exists in parallel with that evidence for lower vertebrates (Lam and Bruce, 1971; Bellve et al., 1975; Platz et al., 1975). A variety of meiotic histones, which replace the usual somatic histones until themselves replaced by protamine-like histones, have also been identified (Kistler and Geroch, 1975; Shires et al., 1975; Grimes et al., 1975). It is possible that these meiotic histones are 'pre-protamines' (Goldberg et al., 1977). Other proteins involved in the rearrangement of sperm chromatin may exist and may also be synthesized late in spermiogenesis: postmeiotic synthesis of non-histone, phenol-soluble acidic chromatin protein(s) has been suggested (Pipkin, 1975).

Another approach to the number of post-meiotically synthesized proteins involves electrophoretic analyses of newly synthesized proteins in separated spermatogenic cells or spermatozoa at various time intervals after labelling. One-dimensional gel electrophoretic analysis of sperm proteins demonstrated that insoluble sperm head proteins were synthesized in mid-spermatids in parallel with the synthesis of protamine-like histone (O'Brien and Bellve, 1980). Two-dimensional gel analyses of separated, spermatogenic cells by one group showed 11 spots unique to post-meiotic stages (Boitani et al., 1980), while our group found 10 cytoplasmic proteins specific to early spermatids, 1 cytoplasmic protein specific to late spermatids, 7 membrane proteins specific to early spermatids and 6 membrane proteins specific to late spermatids - a total of 24 post-meiotic appearing proteins (Kramer and Erickson, 1981b). These are, of course, minimal estimates.

\section{$t$-ALLELE TRANSMISSION RATIO DISTORTION}

Of the genetic variants in a variety of organisms which result in non-Mendelian ratios, perhaps the most interesting are mutations at the $t$-region of the mouse. In addition to unorthodox features of genetic transmission, $t$-alleles have remarkable effects on early embryonic development and differentiation (Gluecksohn-Waelsch and Erickson, 1970; Bennett, 1975; Erickson et al., 1980b). The tail, from which the ' $T$ ' derives, has served as the indicator phenotype for mutations with more profound effects. The dominant $T$ (brachyury) mutation causes a short tail in the heterozygous state. A large number of recessive mutations, $t^{\mathrm{n}}$, interact with $T$ to produce taillessness in compound heterozy. gotes $\left(T / t^{\mathrm{n}}\right)$. Such tailless mice are maintained via a balanced lethal system with the two homozygous types eliminated prenatally (both $T / T$ and $t^{\mathrm{n}} / t^{\mathrm{n}}$ are embryonic lethals). Males (but not females) heterozygous for a $t$-allele transmit it to many more of their progeny than the 50\% dictated by Mendel's laws. Many $t$-alleles recently recovered from wild populations have segregation ratios of greater than 0.95 , while laboratory populations are usually characterized by lower ratios. The ratios vary considerably between individual males carrying a particular $t$-allele as well as between different $t$-alleles (Braden, 1972); there are low distorters as well. However, it is now quite apparent that low (Dunn and Bennett, 1968) is a $t$-allele without $T$-interacting, lethal, or crossover suppression effects (Lyon and Mason, 1977). However, males which are compound heterozygotes for two different $t$-alleles which complement each other (for viability) are sterile.

Most of the known physiological effects of $t$-alleles can be interpreted by postulating that the gene product functions at cell surfaces; thus it has been suggested that the $t$-allele gene product might be detected as a cell surface antigen (Gluecksohn-Waelsch and Erick- 
son, 1971). A cell surface antigen determined by $t$-alleles might be less translocatable across intercellular bridges than a cytosol protein, and haploid gene expression could result in non-equivalent gametes and thus transmission ratio distortion (Erickson, 1978). If a putative $t$-antigen was not translocatable across the intercellular bridges, it should not be an essential component of spermatozoa, since it has been shown that spermatozoa deficient for the entire wild-type chromosomal $T$-region can successfully fertilize eggs (Lyon et al., 1972).

Evidence for the presence of an altered sperm-associated antigen determined by a dominant $T$ allele was found subsequently with a mouse antiserum raised against spermatozoa from mice heterozygous for $T$ (Bennett et al., 1972). However, the relevance of this spermatozoal antigen to the physiology of the $T$-region is questionable as $T$ is silent in terms of sperm function. Further studies claimed partially distinctive antigens associated with several different recessive $t$-alleles, and produced evidence compatible with post-meiotic expression of a putative $t$-antigen in differentially viable $t$ and wild-type spermatozoa (Yanagisawa et al., 1974a, b). Studies of anti-spermatozoal antibodies to spermatozoa from animals bearing various $t$-alleles, and analysis of the cross-reacting components, suggested that a complex antigenic system might be involved (Artzt and Bennett, 1977). Recent extensive experiments have been unable to confirm the existence of putative $t$-antigens on spermatozoa (Goodfellow et al., 1979; Gable et al., 1979).

Transmission ratio distortion can be accounted for by two different mechanisms, either unequal numbers of two kinds of spermatozoa or equal numbers of functionally different spermatozoa are produced. Selective cell death during spermatogenesis could be hypothesized to be involved in the generation of unequal numbers of functionally different spermatozoa. In such an hypothesis, unequal numbers of spermatozoa could result because some chromosomes preferentially segregate to cytoplasm that is destined to die (a hypothesis for segregation distorter in Drosophila - Peacock and Erickson, 1965). However, there is a deficiency of only about $13 \%$ of the cells expected on the basis of mouse spermatogenic kinetics, and these include pre- and post-meiotic cells (Oakberg, $1956 \mathrm{a}, \mathrm{b})$. Thus, non-Mendelian ratios of the magnitude seen with $t$-alleles cannot be explained by this mechanism.

Alternatively, there is evidence which suggests that the transmission ratio distortion controlled by $t$-alleles involves functional differences between spermatozoa bearing different $t$-alleles. Delayed mating, in which fertilization occurs as soon as the spermatozoa reach the fallopian tube, compared to normal mating which requires that sperm remain in the female reproductive tract for several hours before fertilization, nullifies the transmission ratio distortion in the case of several $t$-alleles (Braden, 1958; Yanagisawa et al., 1961; Erickson, 1973; Fig. 3). The fact that the $t$-allele effect can be altered by changing the time of insemination relative to ovulation suggests that there are two classes of spermatozoa with unequal physiological characteristics, which could arise as the result of haploid gene expression. The transmission ratio distortions for the $t^{6}$ and $t^{12}$ alleles found with in vitro fertilization were similar to those found with delayed mating (McGrath and Hillman, 1980, 1981). If verified for other $t$-alleles, this result would suggest that it is the physiological environment rather than the time element which is crucial.

The delayed mating experiments suggest that $t$-allele effects on transmission ratios could be mediated through alterations in spermatozoal metabolism, perhaps with sec- 
LATE MATING

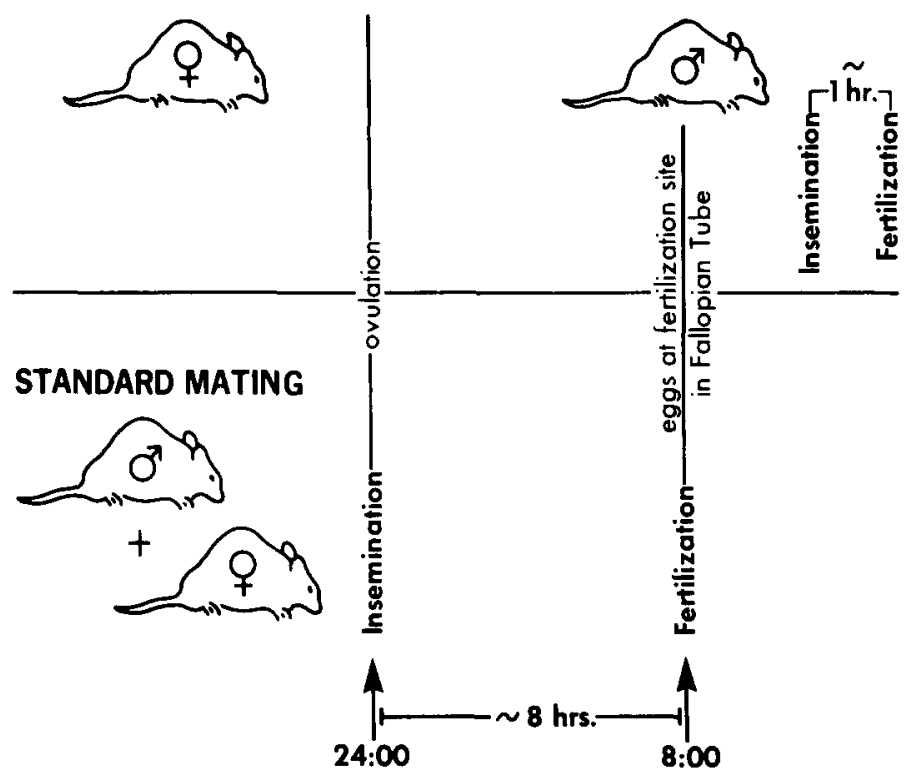

Fig. 3. Delayed mating compared to standard mating. In standard mating, the male is continuously caged with the female which becomes receptive at the time of ovulation (about 24.00 hours) Since the eggs do not reach the fertilization site in the Fallopian tube until 7 or $8 \mathrm{~h}$ later, fertilization occurs after a 7 or $8 \mathrm{~h}$ sojourn by the spermatozoa in the female tract. With late mating, the male is not put into the cage until 08.00 hours, the eggs are already at the fertilization site, and fertilization occurs in about an hour.

ondary effects on sperm motility. These alterations could be related to the lethality of homozygous embryos, cause sterility in complemented males, and be beneficial in sperm in the presence of a wild-type allele. There is some evidence to suggest that $t$-bearing sperm differ in their ability to maintain motility (Yanagisawa, 1965; Katz et al., 1979). Ginsberg and Hillman (1974) found an inverse relationship between the transmission ratio and the NADH/NAD ratio of particular $t$-spermatozoa (from heterozygotes) while a direct correlation of transmission ratios with oxygen uptake was found. These results extend morphologic observations of early lipid accumulations and altered ATP turnover in several lethal $t^{\mathrm{n}}$ homozygotes (Hillman et al., 1970; Nadijcka and Hillman, 1975a, b; Ginsberg and Hillman, 1975). These metabolic defects could reside in mitochondria (Blake, 1977), under nuclear genome control, and, since mitochondria should be less likely to pass through the intercellular bridges connecting spermatids, the products of gene expression involving mitochondria might also not be shared by adjacent spermatocytes or spermatids. This hypothesis is further strengthened by the fact that mitochondria take on an enlarged role in the energy metabolism of sperm. Enzymes which are normally cytoplasmic are found to be purified with mitochondria (lactate dehydrogenase; De Domenech et al., 1970), localized in the midpiece histochemically ( $\alpha$-glycerophosphate dehydrogenase; Posalaky, 1965) or unusually difficult to solubilize (hexokinase; Harrison, 
1971; glucose-6-phosphate dehydrogenase; Sarkar et al., 1977).

A further unifying hypothesis to explain the multiple effects of $t$-alleles might predict that antigens determined or controlled by some portion of the $T$-region are related to membrane transport, hormone receptors, adenylate cyclase or other membrane features affecting intracellular metabolism. This hypothesis gains some credence from the fact that Meruelo and Edidin (1975) have detected $\mathrm{H}-2$ determined differences in hepatic cAMP levels due to altered glucagon binding (Lafuse and Edidin, 1980). The possibility that $H-2$ and $T$ are functionally related has been suggested because of their linkage disequilibrium (Snell, 1968; Hammerberg and Klein, 1975). Neither $H$-2 nor the $T$-region seems to have an effect on spermatozoal cAMP levels (Erickson et al., 1979a) measured under physiological conditions, although differences have been reported (Nadijcka and Hillman, 1980) in the presence of a phosphodiesterase inhibitor.

\section{SPERMATOZOA DIFFERING IN CHROMOSOMAL CONTENT}

Evidence for haploid gene expression is not limited to situations involving single genes. Spermatozoa differing in their chromosomal content may also be functionally different. For example, it is possible that spermatozoa bearing X-or Y-chromosomes express different phenotypes. Attempts to separate X-and Y-bearing spermatozoa by physical methods which do not depend on sperm motility (i.e. the sperm are passive) and those in which sperm motility plays a part (active) must be distinguished. It is frequently assumed that the difference in weight and/or density between an X-and a Y-chromosome would be large enough to allow passive separation. The slight difference in DNA content (about 3\% (Sumner et al., 1971), which represents about 1\% difference in total weight), is unlikely to allow passive physical separation of sperm (Roberts, 1972). In one study it was impossible to separate diploid spermatozoa more than slightly from haploid spermatozoa by density centrifugation (Beatty and Fechheimer, 1972). Thus, if X-and Y-bearing spermatozoa are separable by physical techniques, it may not be because of the slight difference in DNA content but because of differential gene expression in the two types of sperm.

A separation of $\mathrm{X}$ - and Y-bearing sperm under conditions in which each ciliary beat could provide a fractional separation based on the difference in DNA content, i.e. spermatozoal-active separation, is theoretically possible. In this case each ciliary motion provides a 'theoretical plate' for magnifying the minute difference in weight due to the difference between an X-and a Y-chromosome. Again, claims for successful spermatozoal-active separations may be interpreted in terms of differences in gene expression, as well as by differences in DNA content.

Recent data on the possibility of separating X-and Y-bearing spermatozoa have largely depended on staining a fluorescent body (F-body) believed to represent the Y-chromosome in fixed spermatozoa (Barlow and Vosa, 1970). This technique is only readily performed on human spermatozoa. The size of the spermatozoa affects the ease of detecting an F-body (Roberts and Goodall, 1976) but the technique seems well validated (Sumner and Robinson, 1976). Rodents and rabbits are more typical organisms for reproductive studies but evaluating separations by staining for F-bodies in human sperm is considerably easier than evaluation by artificial insemination with separated spermatozoal fractions in 
these animals. Using F-body quantitation, a number of investigators have reported that Y-bearing spermatozoa migrate more rapidly in cervical mucus (Rohde et al., 1973; Goodall and Roberts, 1976; Beck et al., 1976), in a laminar flow set-up in semen extender (Bhattacharya et al., 1977) or in albumin gradients (Ericsson et al., 1973; David et al., 1977). However, two groups have presented negative data on $X$ - and $Y$-sperm separation using the latter technique (Evans et al,, 1975; Ross et al., 1975). The well known slight excess of males at birth is also seen early in pregnancy (Yamamoto et al., 1977), suggesting that this ratio is the result of preferential fertility rather than preferential mortality.

In summary, the many observations of preferential fertilization by Y-chromosome bearing sperm may be more readily explained by post-meiotic gene expression than by the very small difference in amount of DNA in $\mathrm{Y}$ - and $\mathrm{X}$-bearing spermatozoa.

It is a general observation that males, both plant and animal, who are carriers of balanced translocations do not transmit the unbalanced state to their offspring nearly as frequently as do female balanced carriers (Hamerton, 1971; Sears, 1953). This result could be due to a difference in meiotic segregation in the two sexes or to a deficiency in fertilizing ability of sperm with unbalanced chromosomal constitution, i.e. post-meiotic gene expression in sperm. It is difficult to study meiosis in man but there have been a number of studies in other mammals which suggest that both mechanisms are at work in some species. In mice, where decreased transmission of translocations by the male occurs, meiotic nondisjunction was found to be markedly lower in the male than in the female according to one report (Oshimura and Tagaki, 1975). Furthermore, it has been reported that aneuploid sperm produced a significant number of aneuploid zygotes which died early in embryogenesis (Ford, 1972; Gropp, 1971). While these experiments did not provide evidence for post-meiotic gene expression, decreased transmission of radiationinduced deficiencies in male but not in female mice, seems to be explained by selective fertilization and not by differential nondisjunction in the male (Russell and Russell, 1960). In sheep, meiotic studies show a significant number of aneuploid secondary spermatocytes while aneuploid zygotes are not found (Chapman and Bruere, 1975). It therefore appears that aneuploid spermatocytes may preferentially degenerate or produce nonfunctional sperm and, thus, are influenced by their genetic content.

\section{ANTIGENS ON SPERMATOZOA}

Considering this background, what is the evidence for haploid expression of sperm antigens? Since the intercellular bridges connecting post-meiotic cells might limit sharing of membrane components (because of the membrane specializations which maintain them), we believe that cell surface antigens found on spermatozoa could show haploid expression. It is a moot point whether or not the human $\mathrm{A}, \mathrm{B}, \mathrm{O}$ and rhesus blood group antigens are expressed on spermatozoa. Thus, it is not surprising that there is even greater disagreement on whether or not there is haploid expression of such antigens. Gullbring (1957) reported the separation of blood group A spermatozoa from those bearing blood group $B$ in AB individuals by agglutination. These results were apparently confirmed by a variation of this technique (Popivanov and Vulchanov, 1962) and by immunofluorescence (Shahani and Southham, 1962; Kerek, 1964) but not by electrophoresis of antibody-treated spermatozoa (Ackerman, 1969). This discrepancy might be explained by the 
fact that a number of investigators have been able to find A or B substance on spermatozoa of secretors (individuals whose exocrine gland secretions contain soluble blood group substances) but not on the spematozoa of non-secretors. Spermatozoa from an $\mathrm{O}$ nonsecretor can adsorb A or B substance from the seminal plasma of a secretor (Edwards et al., 1964; Boettcher, 1965; Parish et al., 1967; Rangnekar and Rao, 1970). Thus, ABO substance is adsorbed and could not show haploid expression. Detailed studies on the location of blood group glycosyl-transferases in the testis will be needed before the controversies concerning haploid expression of blood group antigens are solved.

Similar controversy surrounds the question of haploid expression of histocompatibility antigens on spermatozoa. It is not clear in all systems whether or not histocompatibility antigens are even expressed on spermatozoa, or whether they are simply adsorbed from seminal plasma. This is a problem encountered in studies of ejaculated human sperm, since seminal plasma does contain HLA antigens (Singal et al., 1971; Singal and Berry, 1972). It is not a problem for the studies of $H-2$ antigens of mice since they are studied on spermatozoa from epididymides and ducti deferentes. The strongest evidence for the direct expression of histocompatibility-related antigens on spermatozoa comes from studies on the development of Ia antigen expression during spermatogenesis. The genes determining these antigens map within the $H-2$ complex. Using mutant mice with germ-cell deficient testes, it was found that Ia antigens are not expressed on spermatogonia or testicular somatic cells but are expressed on primary spermatocytes and on cells at later stages of spermatogenesis (Fellous et al., 1976; Erickson, 1977a, b).

Most of the evidence, however, is against haploid expression of $H-2$ antigens (Goldberg et al., 1970; Erickson, 1972; Johnson and Edidin, 1972). The original suggestion of haploid expression of histocompatibility antigens depended on the finding that a mixture of antibodies to each parental haplotype had an additive cytotoxic action on spermatozoa of heterozygous individuals (Fellous and Dausset, 1970). It seems equally possible, or perhaps more likely, that more sperm are killed when both anti-parental sera are used because more antibody molecules attach to the spermatozoa which are expressing both sets of parental antigens (Kerek and Afzelius, 1972; Fellous and Dausset, 1973). Recent reports that two classes of spermatozoa, each expressing only one parental HLA haplotype, may be separated in ejaculates of HLA heterozygous males (by treatment with antibody to one haplotype and complement, followed by removal of the dead spermatozoa on nylon wool columns) would seem to indicate haploid gene expression but need verification. The separated spermatozoa have then been typed for cis antigens (confirmed by family studies; Arnaiz-Villena and Festenstein, 1976) or used in a blast transformation test to demonstrate haploid expression of HLA-D (Halim and Festenstein, 1975, 1978). In the latter case it is quite possible that antibody blockage of mixed lymphocyte culture stimulating sites, independent of their haploid or diploid expression, was being detected. On the other hand, perhaps a difference in the mode of expression of the antigens on spermatozoa could turn out to be the first major difference in the HLA histocompatibility complex of man and the $H-2$ histocompatibility complex of mouse. However, the putative HLA-D has very different properties on sperm than on lymphocytes (Levis and Dattner, 1979) and some workers find no more stimulation by allogeneic than autologous spermatozoa (Kurpisz and Szymezynski, 1979).

There has been a report that the percentage of males in mice can be decreased from 
$53.4 \%$ to $45.4 \%$ by treatment of sperm with antibody to the male-specific H-Y antigen (Bennett and Boyse, 1973), which might suggest that haploid expression of the H.Y antigen has taken place. Another paper presented a similar result using anti-cock sperm antibody on rabbit sperm (Hancock, 1978); however, the controls had an unexplained excess of males. F-body-positive human spermatozoa are preferentially stained by the lectin phytohaemagglutinin, which suggests haploid expression of some glycoprotein on Y-bearing sperm (Hegde et al., 1981). These observations need to be verified.

\section{CONCLUSIONS}

Although there is strong evidence for post-meiotic RNA synthesis during mammalian spermatogenesis, definitive proof of haploid gene expression of antigens or other markers is lacking. Transmission ratio distortion in $t$-allele-bearing males provides evidence for post-meiotic gene expression since delayed mating experiments argue strongly that there are similar numbers of functionally different spermatozoa in ejaculates of males carrying moderately distorting $t$-alleles. Other possible examples of transmission ratio distortion involve differences in chromosomal content of, or antigens on, sperm. In these instances, gene products from only one, or a few, loci could determine functional differences in the spermatozoa, the products of most other loci being equilibrated through the intercellular bridges. Thus, post-meiotic transcription of a number of loci may occur but the intercellular bridges connecting spermatids would usually maintain gametic equivalence. Membrane components such as cell surface antigens are likely candidates for the demonstration of haploid gene expression since the membrane specialization of the intercellular bridges would probably prevent lateral movement from one spermatid to another.

The fact that transmission ratio distortion has not been found in females can be explained by differences in the timing and physiology of gametogenesis in the two sexes. In contrast to spermatogenesis, where post-meiotic differentiation is extensive, the postmeiotic interval is very short in the maturation of the egg, in the higher vertebrates typically a matter of only a few hours. Thus, it is not surprising that there is a need for postmeiotic gene expression during spermatogenesis but not during oogenesis.

\section{REFERENCES}

Ackerman, D.R. (1969) The adsorption of anti-A and anti-B antibodies on human spermatozoa. Fertil. Steril. 20, 324-334.

Arnaiz-Villena, A. and Festenstein, H. (1976) HLA genotyping by using spermatozoa: evidence for haploid gene expression. Lancet ii, 707-709.

Artzt, K. and Bennett, D. (1977) Serological analysis of sperm of antigenically cross-reacting $T / t$ haplotypes and their recombinants. Immunogenetics 5, 97-107.

Barlow, P. and Vosa, C.G. (1970) The Y chromosome in human spermatozoa. Nature (London) 226, 961-962.

Beams, H.W. and Kessel, R.G. (1976) Cytokinesis: a comparative study of cytoplasmic division in animal cells. Am. Sci. 64, 279-290.

Beatty, R.A. (1970) The genetics of the mammalian gamete. Biol. Rev. 45, 73-120.

Beatty, R.A. and Fechheimer, N.S. (1972) Diploid spermatozoa in rabbit semen and their experimental separation from haploid spermatozoa. Biol. Reprod. 7, 267-277.

Beck, K.J., Herschel, S., Hungershofer, R. and Schwinger, E. (1976) The effect of steroid hormones 
on motility and selective migration of X- and Y-bearing human spermatozoa. Fertil. Steril. 27, $407-412$.

Bellvé, A.R. (1979) The molecular biology of mammalian spermatogenesis. Oxford Rev. Reprod. Biol. $1,159-261$.

Bellvé, A.R., Anderson, E. and Hanley-Bowdoin, L. (1975) Synthesis and amino acid composition of basic proteins in mammalian sperm nuclei. Dev. Biol. 47, 349-365.

Bennett, D. (1975) The T-locus of the mouse. Cell 6, 441-454.

Bennett, D. and Boyse, E.A. (1973) Sex ratio in progeny of mice inseminated with sperm treated with H-Y antiserum. Nature (London) 246, 308-309.

Bennett, D., Goldberg, E., Dunn, L.C. and Boyse, E.A. (1972) Serological detection of a cell-surface antigen specified by the $T$ (Brachyury) mutant gene in the house mouse. Proc. Natl. Acad. Sci. U.S.A. $69,2076-2080$.

Betlach, C.J. and Erickson, R.P. (1976) $28 \mathrm{~S}$ and $18 \mathrm{~S}$ ribonucleic acid from mammalian spermatozoa. J. Exp. Zool. 198, 49-56.

Bhattacharya, B.C., Shome, P., Gunther, A.H. and Evans, B.M. (1977) Successful separation of X and $Y$ spermatozoa in human and bull semen. Int. J. Fertil. 22, 30-55.

Bishop, D.W. (1967) Significance of testicular sorbitol dehydrogenase (SDH). J. Gen. Physiol. 50, 2504 (Abstr.).

Bishop, D.W. (1968) Testicular enzymes as fingerprints in the study of spermatogenesis. In Reproduction and Sexual Behaviour (Diamond, M., ed.), pp. 261-286. Indiana University Press, Bloomington.

Blake, R.L. (1977) Cytochrome $c$ oxidase activity in $T / t^{6}$ (balanced lethal) mutant mice. Biochem. Genet. 15, 785-801.

Blanco, A. and Zinkham, W.H. (1963) Lactate dehydrogenase in human testes. Science 139, 601602.

Bloch, D.P. (1969) A catalog of sperm histones. Genetics 61, 93-112.

Bloom, S.E. and Goodpasture, C. (1976) An improved technique for selective silver staining and nucleolar organizer regions in human chromosomes. Hum. Genet. 34, 199-206.

Boettcher, B. (1965) Human ABO blood group antigens on spermatozoa from secretors and nonsecretors. J. Reprod. Fertil. 9, 267-268.

Boitani, C., Geremia, R., Rossi, R. and Monesi, V. (1980) Electrophoretic pattern of polypeptide synthesis in spermatocy tes and spermatids of the mouse. Cell Differ. 9, 41-49.

Borders, C.L., Jr. and Raftery, M.A. (1968) Purification and partial characterization of testicular hyaluronidase. J. Biol. Chem. 243, 3756-3762.

Bouters, R., Esnault, C., Ortavant, R. and Salisbury, G.W. (1967) Comparison of DNA revealed by Feulgen and by ultra-violet light in rabbit spermatozoa after storage in the male efferent ducts. Nature (London) 213, 181-182.

Braden, A.W.H. (1958) Influence of time of mating on the segregation ratio of alleles at the $T$ locus in the house mouse. Nature (London) 181, 786-787.

Braden, A.W.H. (1972) T-locus in mice: segregation distortion and sterility in the male. In Proceedings, International Symposium on The Genetics of the Spermatozoon (Beatty, R.A. and Gluecksohn-Waelsch, S., eds.), pp. 289-305. Edinburgh.

Brink, R. and Burnham, C.R. (1927) Differential action of the sugary gene in maize on 2 alternative classes of male gametophy tes. Genetics $12,348-378$.

Brock, W.A. (1975) Gene expression during spermatogenesis in the mouse. Genetics 80, S16-17 (Abstr.).

Buckingham, M.E., Caput, D., Cohen, A., Whalen, R.G, and Gros, F. (1974) The synthesis and stability of cytoplasmic messenger RNA during myoblast differentiation in culture. Proc. Natl. Acad. Sci. U.S.A. 71, 1466-1470.

Calvin, H.I. (1976) Comparative analy sis of the nuclear basic proteins in rat, human, guinea pig, mouse and rabbit spermatozoa. Biochim. Biophys. Acta 434, 377-389.

Chapman, H.M. and Bruere, A.N. (1975) The frequency of aneuploidy in the secondary spermatocy tes of normal and Robertsonian translocation-carrying rams. J. Reprod. Fertil. 45, 333-342. 
Chevaillier, P. and Phillipe, M. (1976) In situ detection of a DNA-polymerase activity in the nuclei of mouse spermatozoa. Chromosoma 54, 33-37.

Christiansen, R., Monn, E. and Desautel, M. (1972) Highly specific testicular isozyme of cyclic nucleotide phosphodiesterase associated with sexual maturation. Clin. Res. 20, 252 (Abstr.).

Comings, D.E. and Okada, T.A. (1972) The chromatoid body during mouse spermatogenesis: evidence that it may be formed by the extrusion of nucleolar components. J. Ultrastruct. Res. 39, 15-23.

Cooper, D.W., VandeBerg, J.L., Sharman, G.B. and Poole, W.E. (1971) Phosphoglycerate kinase polymorphism in kangaroos provides further evidence for paternal $\mathrm{X}$ inactivation. Nature (London) New Biol. 230, 155-157.

Daentl, D., Erickson, R.P. and Betlach, C.J. (1977) DNA synthetic capabilities of differentiating sperm cells. Differentiation 8, 159-166.

Daled, H.J. (1951) Étude cytochémique sur l'évolution de l'acide ribonucléique dans la spermatogenèse du rat. Arch. Anat. Microsc. Morphol. Exp. 40, 183-194.

David, G., Jeulin, C., Boyce, A. and Schwartz, D. (1977) Motility and percentage of Y-and YY-bearing spermatozoa in human semen samples after passage through bovine serum albumin. J. Reprod. Fertil. 50, 377-379.

De Domenech, E.M., Domenech, C.E. and Blanco, A. (1970) Distribution of lactate dehydrogenase isozymes in subcellular fractions of rat tissues. Arch. Biochem. Biophys. 141, 147-154.

Dunn, L.C. and Bennett, D. (1968) A new case of transmission ratio distortion in the house mouse. Proc. Natl. Acad. Sci. U.S.A. 61, 570-573.

Dym, M. and Fawcett, D.W. (1971) Further observations on the numbers of spermatogonia, spermatocytes and spermatids connected by intercellular bridges in the mammalian testis. Biol. Reprod. 4, $195-215$.

Edwards, R.G., Ferguson, L.C. and Coombs, R.R.A. (1964) Blood group antigens on human spermatozoa. J. Reprod. Fertil. 7, 153-161.

Epstein, C.J. (1975) Gene expression and mactomolecular synthesis during preimplantation embryonic development. Biol. Reprod. 12, 82-105.

Erickson, R.P. (1972) Alternative modes of detection of $\mathrm{H \cdot 2}$ antigens on mouse spermatozoa. In Proceedings, International Symposium on The Genetics of the Spermatozoon (Beatty, R.A. and Gluecksohn-Waelsch, S., eds.), pp. 191-200. Edinburgh.

Erickson, R.P. (1973) Haploid gene expression versus meiotic drive: the relevance of intercellular bridges during spermatogenesis. Nat. New Biol. 243, 210-212.

Erickson, R.P. (1977a) Gene expression of a region of chromosome 17 during murine spermatogenesis. J. Immunogenet. 4, 353-362.

Erickson, R.P. (1977b) Differentiation and other alloantigens of spermatozoa. In Immunobiology of Gametes (Edidin, M. and Johnson, M.H., eds.), pp. 85-114. Cambridge University Press, Cambridge.

Erickson, R.P. (1978) $t$-alleles and the possibility of post-meiotic gene expression during mammalian spermatogenesis. Fed. Proc. 37, 2517-2521.

Erickson, R.P., Butley, M.S., Martin, S.R. and Betlach, C.J. (1979a) Variation among inbred strains of mice in adenosine $3^{\prime}: 5^{\prime}$ cyclic monophosphate levels of spermatozoa. Genet. Res. 33, 129-136.

Erickson, R.P., Harper, K., Menge, A. and Lee, C.-Y. (1979b) Immunological studies of the spermspecific phosphogly cerate kinase-2 of mice. J. Reprod. Immunol. 1, 185-191.

Erickson, R.P., Erickson, J.M., Betlach, C.J. and Meistrich, M.L. (1980a) Further evidence for haploid gene expression during spermatogenesis: Heterogeneous, poly(A)-containing RNA is synthesized post-meiotically. J. Expt. Zool. 214, 13-20.

Erickson, R.P., Hammerberg, C. and Sanchez, E. (1980b) $t$-mutants in the mouse and alterations in early development. In Proceedings, Current Research Trends in Prenatal Craniofacial Development (Pratt, R.M. and Christiansen, R.L., eds.), pp. 103-118. Elsevier North-Holland, New York.

Erickson, R.P., Kramer, J.M., Rittenhouse, J. and Salkeld, A. (1980c) Quantitation of messenger RNAs during mouse spermatogenesis: protamine-like histone and phosphoglycerate kinase-2 mRNAs increase after meiosis. Proc. Natl. Acad. Sci. U.S.A. 77, 6086-6090.

Ericsson, R.J., Langevi, C.N. and Nishino, M. (1973) Isolation of fractions rich in human $Y$ sperm. Nature (London) 246, 421-424. 
Evans, J.M., Douglas, T.A. and Renton, J.P. (1975) An attempt to separate fractions rich in human Y sperm. Nature (London) 253, 352-354.

Fawcett, D. (1972) Observations on cell differentiation and organelle continuity in spermatogenesis. In Proceedings, International Symposium on The Genetics of the Spermatozoon (Beatty, R.A. and Gluecksohn-Waelsch, S., eds.), pp. 37-68. Edinburgh.

Fawcett, D.W. (1979) The cell biology of gametogenesis in the male. Perspect. Biol. Med. 31, s56s73.

Fawcett, D.W., Eddy, E.M. and Phillips, D.M. (1970) Observations on the fine structure and relationships of the chromatoid body in mammalian spermatogenesis. Biol. Reprod. 2, 129-153.

Fechheimer, S. (1970) Genetic aspects of testicular development and function. In The Testis, Vol. 3 (Johnson, A.D., Gomes, W.R. and Vandemark, N.L., eds.), pp. 1-40. Academic Press, New York.

Fellous, M. and Dausset, J. (1970) Probable haploid expression of HL-A antigens on human spermatozoon. Nature (London) 225, 191-193.

Fellous, M. and Dausset, J. (1973) Histocompatibility antigens of human spermatozoa. In Immunology of Reproduction (Bratanov, K., ed.), pp. 332-338. Bulgarian Academy of Science, Sofia.

Fellous, M., Erickson, R.P., Gachelin, G. and Jacob, F. (1976) The time of appearance of Ia antigens during spermatogenesis in the mouse. Transplantation 22, 440-444.

Ford, C.E. (1972) Gross genome unbalance in mouse spermatozoa: does it influence the capacity to fertilize? In Proceedings, International Symposium on The Genetics of the Spermatozoon (Beatty, R.A. and Gluecksohn-Waelsch, S., eds.), pp. 359-369. Edinburgh.

Fritz, I.B. (1973) Selected topics on the biochemistry of spermatogenesis. In Current Topics in Cellular Recognition (Horecker, B., Bernard, L. and Stadtman, E.R., eds.), pp. 129-174. Academic Press, New York.

Gable, R.J., Levinson, J.R., McDevitt, H.O. and Goodfellow, P.N. (1979) Assay for antibody mediated cy totoxicity of mouse spermatozoa by ${ }^{86}$ rubidium release. Tissue Antigens $13,177-185$.

Geremia, R., Biotani, C., Conti, M. and Monesi, V. (1977) RNA synthesis in spermatocy tes and spermatids and preservation of meiotic RNA during spermiogenesis in the mouse. Cell Differ. 5, 343355.

Geremia, R., D'Agostino, A. and Monesi, V. (1978) Biochemical evidence of haploid gene activity in spermatogenesis of the mouse. Exp. Cell Res. 111, 23-30.

Ginsberg, L. and Hillman, N. (1974) Meiotic drive in $t^{\mathrm{n}}$-bearing mouse spermatozoa: A relationship between aerobic respiration and transmission frequency. J. Reprod. Fertil. 38, 157-163.

Ginsberg, L. and Hillman, N. (1975) ATP metabolism in $t^{\mathrm{n}} / t^{\mathrm{n}}$ mouse embryos. J. Embryol. Exp. Morphol. 33, 715-723.

Gledhill, B.L., Gledhill, M.P., Rigler, R. Jr. and Ringertz, N.R. (1966) Changes in deoxyribonucleoprotein during spermiogenesis in the bull. Exp. Cell Res. 41, 652-665.

Gluecksohn-Waelsch, S. and Erickson, R.P. (1970) The T-locus of the mouse: Implications for mechanisms of development. Current Topics Develop. Biol. 5, 281-316.

Gluecksohn-Waelsch, S. and Erickson, R.P. (1971) Cellular membranes: A possible link between $H-2$ and $T$-locus effects. In Immunogenetics of the $H-2$ System (Lengerova, A. and Vojtiskova, M., eds.). Karger, Basel. pp. 120-122.

Goldberg, E. and Hawtrey, C. (1967) The ontogeny of sperm specific lactate dehydrogenase in mice. J. Exp. Zool. 164, 309-316.

Goldberg, E.H., Aoki, T., Boyse, E.A. and Bennett, D. (1970) Detection of $H-2$ antigens on mouse spermatozoa by the cy totoxicity test. Nature (London) $228,570-572$.

Goldberg, R.B., Geremia, R. and Bruce, W.R. (1977) Histone synthesis and replacement during spermatogenesis. Differentiation 7, 167-180.

Goodall, H. and Roberts, A.M. (1976) Differences in motility of human X-and Y-bearing spermatozoa. J. Reprod. Fertil. 48, 433-436.

Goodfellow, P.N., Levinson, J.P., Gable, R.J. and McDevitt, H.O. (1979) Analysis of anti-sperm sera for $T / t$ locus-specific antibody. J. Reprod. Immunol. 1, 11-21.

Grimes, S.R. Jr., Platz, R.D., Meistrich, M.L. and Hnilica, L.S. (1975) Partial characterization of a new basic nuclear protein from rat testis elongated spermatids. Biochem. Biophys. Res. Commun. 67, $182-189$. 
Grootegoed, A.J., Grolle-Hey, A.H., Rommerts, F.F.G. and van der Molen, H.J. (1977) Ribonucleic acid synthesis in vitro in primary spermatocytes isolated from rat testis. Biochem. J. 168, 23-31.

Gropp, A. (1971) Reproductive failure due to fetal aneuploidy in mice. In Proceedings, 7 th World Congress on Fertility and Sterility, Tokyo/Kyoto. International Congress Series 278, pp. 326-330. Excerpta Medica, New York.

Gullbring, B. (1957) Investigation on the occurrence of blood group antigens in spermatozoa from man, and serological demonstration of the segregation of characters. Acta Med. Scand. 159, 169172.

Halim, K. and Festenstein, H. (1975) HLA-D on sperm is haploid, enabling use of sperm for HLA-D typing. Lancet ii, 1255-1256.

Halim, K. and Festenstein, H. (1978) Sperm induced lymphocyte inactivation. Lancet i, 937.

Hamerton, J.L. (1971) Human Cytogenetics, p. 412. Academic Press, New York.

Hammerberg, C. and Klein, J. (1975) Linkage disequilibrium between $\mathrm{H}-2$ and $t$ complexes in chromosome 17 of the mouse. Nature (London) 258, 296-299.

Hancock, R.J.T. (1978) Comparison of effects of normal rabbit sera and anti-cock sperm sera on rabbit sperm, including comparison of effects on the sex ratio. Biol. Reprod. 18, 510-515.

Harpold, M.M., Evans, R.M., Salditt-Georgieff, M. and Darnell, J.E. (1979) Production of mRNA in Chinese hamster cells: Relationship of the rate of synthesis to the cytoplasmic concentration of nine specific mRNA sequences. Cell 17, 1025-1035.

Harrison, R.A.P. (1971) Glycolytic enzymes in mammalian spermatozoa. Activities and stabilities of hexokinase and phosphofructokinase in various fractions from sperm homogenates. Biochem. J. $124,741-750$.

Hecht, N.B. (1974) A DNA polymerase isolated from bovine spermatozoa. J. Reprod. Fertil. 41, $345-$ 354.

Hecht, N.B., Farrell, D. and Williams, J.L. (1979) DNA polymerases in mouse spermatogenic cells separated by sedimentation velocity. Biochim. Biophys. Acta 561, 358-368.

Hegde, U.C., Shastry, P.R. and Rao, S.S. (1981) Phy tohemagglutinin as a molecular probe to study the membrane constituents of human X-and Y-bearing spermatozoa. J. Reprod. Immunol. 2, 351357.

Hennig, B. (1975) Change of cytochrome $c$ structure during development of the mouse. Eur. J. Biochem. 55, 167-183.

Hillman, N., Hillman, R. and Wileman, G. (1970) Ultrastructural studies of cleavage stage $t^{12} / t^{12}$ mouse embryos. Am. J. Anat. 128, 311-340.

Ito, M. (1966) Histochemical observations of oxidative enzymes in irradiated testis and epididymis. Radiat. Res. 28, 266-277.

Johnson, M.H, and Edidin, M. (1972) $H \cdot 2$ antigens on mouse spermatozoa. Transplantation 14,781 786.

Kalt, M.R. (1979) In vitro synthesis of RNA by Xenopus spermatogenic cells. I. Evidence for polyadenylated and non-polyadenylated RNA synthesis in different cell populations. J. Exp. Zool. $208,77-95$.

Kaput, J. and Sneider, T.W. (1979) Methylation of somatic vs. germ germ cell DNAs analyzed by restriction endonuclease digestions. Nucleic Acids Res. 7, 2303-2321.

Katz, D.F., Erickson, R.P. and Nathanson, M. (1979) Beat frequency is bimodally distributed in spermatozoa from $T / t^{12}$ mice. J. Exp. Zool. 210, 529-535.

Katzen, H.M. (1967) The multiple forms of mammalian hexokinase and their significance to the action of insulin. Adv. Enzyme Regul. 5, 335-356.

Kerek, G. (1974) Distribution of the blood group antigens A and B on human spermatozoa. Int. J. Fertil. 19, 181-191.

Kerek, G. and Afzelius, A. (1972) The HL-A antigens on human spermatozoa. Int. J. Fertil. 17, 120 126.

Kettaneh, N.P. and Hartl, D. (1976) Histone transition during spermiogenesis is absent in Segregation Distorter Males of Drosophila melanogaster. Science 193, 1020-1021.

Kierszenbaum, A.L. and Tres, L.L. (1974a) Transcription sites in spread meiotic prophase chromosomes from mouse spermatocytes. J. Cell Biol. 63, 923-925. 
Kierszenbaum, A.L. and Tres, L.L. (1974b) Nucleolar and perichromosomal RNA synthesis during meiotic prophase in the mouse testis. J. Cell Biol. 60,39-53.

Kierszenbaum, A.L. and Tres, L.L. (1975) Structural and transcriptional features of the mouse spermatid genome. J. Cell Biol. 65, 258-270.

$\mathrm{Kim}, \mathrm{C}$. (1980) Isolation and properties of somatic and testicular cytochrome $c$ from rat tissues. Arch. Biochem. Biophys. 203, 519-528.

Kistler, W.S. and Geroch, M.E. (1975) An unusual pattern of lysine rich histone components is associated with spermatogenesis in rat testis. Biochem. Biophys. Res. Commun. 63, 378-384.

Kofman-Alfaro, S. and Chandley, A.C. (1970) Meiosis in the male mouse. An autoradiographic investigation. Chromosoma 31, 404-420.

Kramer, J.M. and Erickson, R.P. (1981a) Developmental programs of PGK-1 and PGK-2 isozymes in spermatogenic cells of the mouse: Specific activities and rates of synthesis. Dev. Biol., in press.

Kramer, J.M. and Erickson, R.P. (1981b) Analysis of stage-specific protein synthesis during spermatogenesis of the mouse by two-dimensional gel electrophoresis. J. Reprod. Fertil., in press.

Kurpisz, M., Szymezynski, G. (1979) Evaluation of surface markers on lymphocy tes after culture with human spermatozoa. Int. J. Androl. 2, 101-109.

Lafuse, W. and Edidin, M. (1980) Influence of the mouse major histocompatibility complex, $H-2$, on liver adenylate cyclase activity and on glucagon binding to liver cell membranes. Biochemistry 19 , 49-54.

Lam, D.M.K. and Bruce, W.R. (1971) The biosynthesis of protamine during spermatogenesis of the mouse: extraction, partial characterization, and site of synthesis. J. Cell. Physiol. 78, 13-24.

Lam, D.M.K., Furrer, R. and Bruce, W.R. (1970) The separation, physical characterization, and differentiation kinetics of spermatogonial cells of the mouse. Proc. Natl. Acad. Sci. U.S.A. 65, 192-199.

Lavon, U., Volcani, R. and Danon, D. (1971) The proteins of bovine spermatozoa from the caput and cauda epididymidis. J. Reprod. Fertil. 24, 219-232.

Lee, I.P. and Dixon, R.L. (1972) Antineoplastic drug effects on spermatogenesis studied by velocity sedimentation cell separation. Toxicol. Appl. Pharmacol. 23, $20-41$.

Levis, W.R. and Dattner, A.M. (1979) Ultraviolet (UV) sensitive leukocyte allostimulation cross-reacts with UV resistant sperm. J. Immunol. 122, 1986-1990.

Loir, M. (1972) Métabolism de l'acide ribonucléique et des protéines dans les spermatocytes et les spermatides du belier (Ovis aries). Ann. Biol. Anim. Biochim. Biophys. 12, 203-219.

Lyon, M.F. and Mason, I. (1977) Information on the nature of $t$-haplotypes from the interaction of mutant haplotypes in male fertility and segregation ratio. Genet. Res. 29, 255-266.

Lyon, M.F., Glenister, P.H. and Hawkes, S.G. (1972) Do the $H-2$ and $T-10 c i$ of the mouse have a function in the haploid phase of sperm? Nature 240, 152-153.

Males, J.L. and Turkington, R.W. (1970) Hormonal regulation of hyaluronidase during spermatogenesis in the rat. J. Biol. Chem. 245, 6329-6334.

Mancini, R.E., Alonso, A., Barquet, J., Alvarez, B. and Nemirovsky, M. (1964) Histo-immunological localization of hyaluronidase in the bull testis. J. Reprod. Fertil. 8, 325-330.

McGrath, J. and Hillman, N. (1980) The in vitro transmission frequency of the $t^{6}$ allele. Nature (London) $283,479-481$.

McGrath, J. and Hillman, N. (1981) The in vitro transmission frequency of the $t^{12}$ mutation in the mouse. J. Embryol. Exp. Morphol. 60, 141-151.

Meistrich, M.L. (1972) Separation of mouse spermatogenic cells by velocity sedimentation. J. Cell. Physiol. 80, 299-312.

Meistrich, M.L., Bruce, W.R. and Clermont, Y, (1973) Cellular composition of fractions of mouse testis cells following velocity sedimentation separation. Exp. Cell Res. 79, 213-227.

Meistrich, M.L., Reid, B.O. and Barcellona, W.J. (1975) Meiotic DNA synthesis during mouse spermatogenesis. J. Cell Biol. 64, 211-222.

Meistrich, M.L., Trostle, P.K., Fraport, M. and Erickson, R.P. (1977) Biosynthesis and localization of lactate dehydrogenase $X$ in pachytene spermatocytes and spermatids of mouse testes. Dev. Biol. 60, 428-441.

Meizel, S., Bogg, D. and Cotham, J. (1971) Electrophoretic studies of esterases of bull spermatozoa cy toplasmic droplets and seminal plasma. J. Histochem. Cy tochem. 19, 226-231. 
Meruelo, D. and Edidin, M. (1975) Association of mouse liver adenosine 3':5'-cyclic monophosphate (cyclic AMP) levels with Histocompatibility-2 genotype. Proc. Natl. Acad. Sci. U.S.A. 72, 2644 2648.

Midgely, A.R. Jr., Gay, W.L., Keyes, P.L. and Hunter, J.S. (1973) Human reproductive endocrinology. In Human Reproduction (E.S.E. Hafez and T.N. Evans, eds.), pp. 201-236. Harper and Row, New York.

Moens, P.B. and Go, V.L.W. (1972) Intercellular bridges and division patterns of rat spermatogonia. Z. Zellforsch. Mikrosk. Anat. 127, 201-208.

Monesi, V. (1962) Autoradiographic study of DNA synthesis and the cell cycle in spermatogonia and spermatocytes of mouse testis using tritiated thymidine. J. Cell Biol. 14, 1-18.

Monesi, V. (1965) Differential rate of ribonucleic acid synthesis in the autosomes and sex chromosomes during male meiosis in the mouse. Chromosoma 17, 11-20.

Monesi, V. (1967) Ribonucleic acid and protein synthesis during differentiation of male germ cells in the mouse. Arch. Anat. Microscop. Morphol. Exp. 56, 61-74.

Moore, G.P.M. (1971) DNA-dependent RNA synthesis in fixed cells during spermatogenesis in mouse. Exp. Cell Res. 68, 462-465.

Muramatsu, M., Utakoji, T. and Sugano, H. (1968) Rapidly-labeled nuclear RNA in Chinese hamster testis. Exp. Cell Res. 53, 278-283.

Nadijcka, M. and Hillman, N. (1975a) Studies of $t^{6} / t^{6}$ mouse embryos. J. Embryol. Exp. Morphol. $33,697-713$.

Nadijcka, M. and Hillman, N. (1975b) Autoradiographic studies of $t^{\mathrm{n}} / t^{\mathrm{n}}$ mouse embryos. J. Embryol. Exp. Morphol. 33, 725-730.

Nadijcka, M. and Hillman, N. (1980) Differences in cAMP levels in $t^{\mathrm{n}}$ and non- $t^{\mathrm{n}}$-bearing mouse spermatozoa. Biol. Reprod. 22, 1102-1105.

Oakberg, E.F. (1956a) A description of spermiogenesis in the mouse and its use in analysis of the cycle of the seminiferous epithelium and germ cell renewal. Am. J. Anat. 99, 391-413.

Oakberg, E.F. (1956b) Duration of spermatogenesis in the mouse and timing of stages of the cycle of the seminiferous epithelium. Am. J. Anat. 99, 507-516.

O'Brien, D.A. and Bellve, A.R. (1980) Protein constituents of the mouse spermatozoon II. Temporal synthesis during spermatogenesis. Dev. Biol. 75, 405-418.

Oshimura, M. and Tagaki, N. (1975) Meiotic disjunction in T(14;15)6Ca heterozygotes and fate of chromosomally unbalanced gametes in embryonic development. Cy togenet. Cell Genet. 15, 1-16.

Parish, W.E., Carron-Brown, J.A. and Richards, C.B. (1967) The detection of antibodies to spermatozoa and to blood group antigens in cervical mucus. J. Reprod. Fertil. 13, 469-483.

Parvinen, M. and Jokelainen, P.T. (1974) Rapid movements of the chromatid body in living early spermatids of the rat. Biol. Reprod. 11,85-92.

Parvinen, L.-M., Jokelainen, P.T. and Parvinen, M. (1978) Chromatoid body and haploid gene activity: actinomycin $\mathrm{D}$ induced morphological alterations. Hereditas $88,75-80$.

Peacock, W.J. and Erickson, J. (1965) Segregation-distortion and regularly nonfunctional products of spermatogenesis in Drosophila melanogaster. Genetics 51, 313-328.

Pipkin, J.L. Jr. (1975) The isolation and characterization of individual phenol-soluble nuclear proteins from various reproductive cells during bovine spermatogenesis. Exp. Cell Res. 91, 372-380.

Platz, R.D., Grimes, S.R., Meistrich, M.L. and Hnilica, L.S. (1975) Changes in nuclear proteins of rat testis cells separated by velocity sedimentation. J. Biol. Chem. 250, 5791-5800.

Popivanov, R. and Vulchanov, V.H. (1962) Segregation of man's AB-group spermatozoa in A- and Bspermatozoa through agglutination with immune anti-A rabbit serum. Z. Immun. Exp. Ther. 124, $206-210$.

Posalaky, Z. (1965) Activity of different dehydrogenases and diaphorases in the spermatogenesis of the rat, and its relation to motility. Acta Histochem. 20, 86-90.

Radu, F. and Voisin, G.A. (1975) Ontogenesis of spermatozoa autoantigens in guinea pigs. Differentiation 3, 107-114.

Rangnekar, K.N. and Rao, S.S. (1970) The source of blood group antigens on spermatozoa and their significance. Int. Arch. Allergy Appl. Immunol. 37, 49-53. 
Roberts, A.M. (1972) Gravitational separation of X and Y spermatozoa. Nature (London) 238, 223225.

Roberts, A.M. and Goodall, H. (1976) Y chromosome viability in quinacrine-stained human spermatozoa. Nature (London) 262, 493-494.

Rohde, W., Porstmann, T. and Dorner, G. (1973) Migration of Y-bearing human spermatozoa in cervical mucus. J. Reprod. Fertil. 33, 167-169.

Ross, A., Robinson, J.A. and Evans, H.J. (1975) Failure to confirm separation of X- and Y-bearing human sperm using BSA gradients. Nature (London) 253, 354-355.

Russell, L.B. and Russell, W.L. (1960) Genetic analysis of induced deletions and of spontaneous nondisjunction involving chromosome 2 of the mouse. J. Cell. Comp. Physiol. 56 (Suppl. 1), 169-188.

Salisbury, G.W., Birge, W.J., de la Torre, L., and Lodge, J.R. (1961) Decrease in nuclear Feulgenpositive material (DNA) upon aging and in vitro storage of bovine spermatozoa. J. Biophys. Biochem. Cytol. 10, 353-359.

Sarkar, S., Nelson, A.J. and Jones, O.W. (1977) Glucose-6-phosphate dehydrogenase (G6PD) activity of human sperm. J. Med. Genet. 14, 250-255.

Schleiermacher, E. and Schmidt, W. (1973) The local control of mammalian spermatogenesis. Humangenetik 19, 75-98.

Schmid, M., Hofgartner, F.J., Zenzes, M.T. and Engel, W. (1977) Evidence for postmeiotic expression of ribosomal RNA genes during male gametogenesis. Hum. Genet. 38, 279-284.

Sears, E.R. (1953) Nullisomic analysis in common wheat. Am. Nat. 87, 245-252.

Shahani, S. and Southam, A.L. (1962) Immunofluorescent study of the ABO blood group antigens in human spermatozoa. Am. J. Obst. Gynecol. 84, 660-666.

Shires, A., Carpenter, M.P. and Chalkley, R. (1975) New histones found in mature mammalian testes. Proc. Natl. Acad. Sci. U.S.A. 72, 2714-2718.

Singal, D.P. and Berry, R. (1972) Soluble HL-A antigens. Localization in the human seminal plasma fraction. Transplantation 13,441-442.

Singal, D.P., Berry, R. and Naipaul, N. (1971) HL-A inhibiting activity in human seminal plasma. Nat. New Biol, 233, 61-62.

Smyth, D.R. and Stern, H. (1973) Repeated DNA synthesized during pachytene in Lilium henryi. Nat. New Biol. 245, 94-96.

Snell, G.D. (1968) The H-2 locus of the mouse: observations and speculations concerning its comparative genetics and its polymorphisms. Folia Biol. 14, 335-358.

Soderstrom, K.-O. and Parvinen, M. (1976) Incorporation of $\left[{ }^{3} \mathrm{H}\right]$ uridine by the chromatoid body during rat spermatogenesis. J. Cell Biol. 70, 239-246.

Sosa, A., Altomirano, E., Hernandez, P. and Rosado, A. (1972) Developmental pattern of rat testis hexokinase. Life Sci. 11, 499-510.

Stambaugh, R. and Buckley, J. (1969) Identification and subcellular localization of the enzymes effecting penetration of the zona pellucida by rabbit spermatozoa. J. Reprod. Fertil. 19, 423-432.

Stanley, R.G. and Linskens, H.F. (1974) Pollen, p. 189. Springer-Verlag, New York.

Sumner, A.T. and Robinson, J.A. (1976) A difference in dry mass between the heads of X- and Y-bearing human spermatozoa. J. Reprod. Fertil. 48, 9-15.

Sumner, A.T., Robinson, J.A. and Evans, H.J. (1971) Distinguishing between $X, Y$, and $Y Y$-bearing human spermatozoa by fluorescence and DNA content. Nat. New Biol. 229, 231-233.

Turkington, R.W. and Majumder, G.C. (1975) Gene activation during spermatogenesis. J. Cell. Physiol. $85,495-508$.

VandeBerg, J.L. and Blohm, S.V. (1977) An allelic isozyme of mouse PGK-B with low activity. J. Exp. Zool. 201, 479-483.

VandeBerg, J.L., Cooper, D.W. and Close, P.J. (1976) Testis specific phosphoglycerate kinase B in mouse. J. Exp. Zool. 198, 231-240.

Vernon, R.G., Go, V.L.W. and Fritz, I.B. (1971) Studies on spermatogenesis in rats. Il. Evidence that carnitine acetyltransferase is a marker enzyme for the investigation of germ cell differentiation. Can. J. Biochem. 49, 761-767.

Witkin, S.S. and Bendich, A. (1977) DNA synthesizing activity in normal human sperm. Exp. Cell Res. 106, 47-54. 
Wudl, L. and Chapman, V.M. (1976) The expression of $\beta$-glucuronidase during preimplantation development of mouse embryos. Develop. Biol. 48, 104-109.

Yamamoto, M., Ito, T. and Watanabe, G. (1977) Determination of prenatal sex ratio in man. Hum. Genet. 36, 265-269.

Yanagisawa, K. (1965) Studies on the mechanism of abnormal transmission ratios at the $T$-locus in the house mouse. II. Test for physiological differences between $t$ - and $T$-bearing sperm manifested in vitro. Jap. J. Genet. 40, 87-92.

Yanagisawa, K., Dunn, L.C. and Bennett, D. (1961) On the mechanism of abnormal transmission ratios at $T$ locus in the house mouse. Genetics 46, 1635-1644.

Yanagisawa, K., Bennett, D., Boyse, E.A., Dunn, L.C. and Dimeo, A. (1974a) Serological identification of sperm antigens specified by lethal t-alleles in the mouse. Immunogenetics 1, 57-67.

Yanagisawa, K., Pollard, D.R., Bennett, D., Dunn, L.C. and Boyse, E.A. (1974b) Transmission ratio distortion at the $T$-locus: Serological identification of two sperm populations in $t$-heterozygotes. Immunogenetics 1, 91-96.

Zimmering, S., Sandler, L. and Nicoletti, B. (1970) Mechanisms of meiotic drive. Ann. Rev. Genet. 4, $409-436$. 